\title{
PETER ThONNING AND
}

\section{THE NATURAL HISTORICAL}

COLLECTIONS OF DENMARK'S

PRINCE Christian (VIII),

1806-07

\section{Daniel Hopkins}

One of the finest natural historical collections in Denmark in the first half of the nineteenth century, toward the end of the age of great private cabinets, was that of King Christian VIII (1786-1848, king from 1839).' It was founded as the young Prince Christian's instructional collection; the teaching took a strong hold on him, and the prince in time came to possess "a mineralogical and malacological collection of real scientific significance», a collection "to be reckoned with". ${ }^{2}$

It was Prince Christian's personal collection, but, here at the social boundary between the private sphere and the state, the princely collection is best regarded as a national institution. Christian's collections are now incorporated in the scientific museums of the University of Copenhagen. ${ }^{3}$

The curator of the collection from the time Prince Christian was seven years old until 1805 was Hans Severin Holten. ${ }^{4}$ The collection's best known curator was Edouard Romeo Vargas Bedemar, a most remarkable figure of Danish mineralogy, who came to Denmark from Italy in 1809. ${ }^{5}$ Between the tenures of Holten and
Vargas Bedemar, from 1806 to 1809 , Prince Christian's museum was supervised by Peter Thonning, who is known mainly for his West African botanical expedition. ${ }^{6}$ His curatorship has received little notice, although a lively, if brief record of it survives at the Rigsarkiv (the Danish National Archives). A series of letters from Thonning to Prince Christian, preserved among the papers of the royal house, casts a fleeting light on the prince's involvement in the Copenhagen market in natural historical specimens in 1806 and 1807.7 Prince Christian's entomological and mineralogical collections were quite significantly augmented in this period. 
PETER THONNING'S RECRUITMENT INTO THE ROYAL HOUSEHOLD

The well-respected Holten, in addition to his responsibility for the prince's museum, was entrusted with first Prince Christian's and later his younger brother Frederik Ferdinand's instruction in the natural sciences. ${ }^{8}$ In a year-end report to Crown Prince Frederik (VI) shortly before Christmas, 1805, Holten lamented the state of Prince Ferdinand's education, which had been much disrupted." He was of course determined to press on, and he expressed himself especially glad to be able to make use of Prince Christian's "handsome collection», which helped instill in the younger prince "sensibility to the admirable beauty, order, and harmony in nature, and give him a conception of [science's and natural history's] use and significance for the state".

Within a few days of writing this letter, Holten was suddenly dead. ${ }^{10}$ Another of Prince Ferdinand's teachers, Morten Sommer, evidently charged with finding a suitable replacement, undertook to consult Lord High Steward A. W. Hauch, himself a man of science and keeper of the royal Kunstkammer, and Christian Frederik Schumacher, the distinguished botanist, mineralogist, chemist, anthropologist, and surgeon." On January 31, 1806, Sommer reported to High Steward Frederik von Blücher, who had supervision of Prince Ferdinand's education, that he had been that day to talk to Schumacher. ${ }^{12}$

Herr Professor recommended strongly a young man, Peder Tonning, about 26 or 28 years old, not only as a capable and talented man of science, al- though he apparently is not at all what one would call learned, which is not needed, either, to be a child's tutor; but he is, I was told, a man of sound knowledge and also - of this Prof. Schumacher assured me - an honest and respectable character. The Professor has already spoken to H. H. Prince Christian about this man and affirms that he knows him well. Tonning is likewise known by $\mathrm{H}$. Excellence Count Schimmelmann and others in the Finance Department, to which he delivered a precise scientific report of a voyage he made to the Coast of Guinea with natural historical and economic objects in view. His way of thinking and character Prof. Schumacher knows to be especially sound.

Peter Thonning, born in Copenhagen in 1775 and thirty years old at this time, had been recruited out of the Royal Surgeon's Academy in 1799 for a "scientific journey" to the Danish establishments on the Guinea Coast between Accra and the Volta River, in what is today Ghana. ${ }^{13}$ Denmark's ban on its citizens' involvement in the Atlantic slave trade was imminent, and the great Danish West Indian sugar plantations were understood to be doomed; the climate and flora of the territory around the Danish forts in West Africa were therefore becoming matters of substantial government interest. Thonning had returned from the coast of Africa full of dreams for the establishment of plantation agriculture in the Danish territory there, a project that Finance Minister Schimmelmann held dear. ${ }^{14}$

The instructions dispatching Thonning to Africa had been written by Niels Tønder Lund, a senior functionary of the General Customs Chamber, which had administrative jurisdiction over the Danish Atlantic tropical colonies. ${ }^{15}$ Tønder Lund, one of the leading men of 
the central administration, was an important figure of Danish natural history at the end of the eighteenth century; his insect collection was regarded as one of the best in Northern Europe. ${ }^{16}$ In 1789 , Tønder Lund had taken a prominent part in the foundation of the Natural History Society, in collaboration with P. C. Abildgaard, in his day president of the Agricultural Society and secretary of the Royal Danish Academy of Sciences and Letters; P. F. Suhm, the historian and bibliophile; Lorenz Spengler, the conchologist; and Ove Sehested, of the Commerce Department; among others. ${ }^{17}$ The Society was organized to make good the University of Copenhagen's failure to provide a course of studies in natural history, and it indeed appears to have succeeded in bringing natural history into the academic mainstream. ${ }^{18}$ The Society provided regular instruction in botany, zoology, and mineralogy, subjected its students to a public terminal examination, and maintained a museum and botanical garden. It provided a forum, in particular, for the work and instruction of the renowned botanist Martin Vahl, one of Linnæus's last and best students; Schumacher was another of the lecturers, and the royal tutor Holten worked with the Society's collections for a time. ${ }^{19}$ No lists of those attending the Natural History Society's lectures survive, but Peter Thonning names Vahl and Schumacher as his teachers in an 1809 résumé, and he appears to have enjoyed close intellectual relations with Tønder Lund. The ideals and concerns of Danish natural history, which was highly patriotic and economic in its thrust, suffused Thonning's experience in Africa. He spent three years on the Guinea
Coast and brought back to Copenhagen an extremely significant botanical collection, from which he was able to supply many important Danish collections with specimens. ${ }^{20}$ His botanical work in Africa was very highly regarded in his day and has remained of interest down through the generations. ${ }^{21} \mathrm{He}$ also provided African insects to the great Moltke collection. ${ }^{22}$ No indication that Thonning collected minerals in Africa has been found, but he studied the soils in the various areas he visited quite closely. ${ }^{23}$ Upon his return to Denmark, he appears to have worked personally with Vahl. ${ }^{24}$ After Vahl's early death, in 1805, Thonning, with Tønder Lund and J. W. Hornemann, of the Botanical Gardens, undertook the publication of portions of the great botanist's massive opus. ${ }^{25}$

Thonning was not a wealthy man, however, and, having abandoned medicine to undertake his journey to Africa, he remained without a regular living. ${ }^{26}$ The royal family's interest in him was presumably very welcome, and he began work as Prince Ferdinand's tutor on February 10,1806 . Sommer was pleased to report a week later: "This man's aspect cannot otherwise than inspire in the prince interest and respect». In his own letter to Blücher, Thonning reported that he would concentrate first on electricity, where Holten had left off. ${ }^{27} \mathrm{He}$ would tutor the prince for ten hours each week. His first impression, he said, was that the prince would be a good student.

Weekly reports on Prince Ferdinand's education are preserved, and it appears that the prince was not in fact a model pupil; displays of diligence were regularly followed by periods of inattention and 
152 apathy, but Thonning appears to have acquitted himself well. ${ }^{28}$ In October, 1806, the prince's new governor, Johan Frederik Bardenfleth, reported to Crown Prince Frederik that he had been reviewing the substance and manner of Frederik Ferdinand's instruction. ${ }^{29}$ Of Peter Thonning he wrote:

Mr. Thonning's cheerful but firm method I cannot praise enough. If he should have any fault, it would perhaps be that he at one time went a little too fast. ... According to the plan still followed from the late Holten's time, physics and natural history were jumbled together and fragmented. It seemed to me that too much weight was laid on natural history proper, especially botany. I spoke with $\mathrm{Mr}$. Thonning about this and he entered with the most forthcoming good will into my reasoning. We soon agreed that physics and especially mechanics was the main thing and that botany should be limited to knowledge of the most important domestic agricultural and commercial plants.

When the British attacked Copenhagen in 1807, Thonning and Sommer escorted Prince Ferdinand to safety in Odense. ${ }^{30}$ Thonning's own botanical collections and notes were destroyed in the bombardment, and it appears that he may have lost heart: he never published the botanical and geographical description of the Danish stretch of the Guinea Coast that he had contemplated. ${ }^{31}$ When his African flora was published twenty years later from duplicate specimens, it was with his teacher Schumacher's name on the title page. ${ }^{32}$

\section{THONNING AND PRINCE CHRISTIAN'S COLLECTIONS IN NATURAL HISTORY}

Upon his appointment as Prince Frederik Ferdinand's tutor, Thonning also took over the supervision of Prince Christian's natural historical collections. Eight letters from Thonning to the prince regarding the collections are preserved among Christian's archives at the Rigsarkiv; they date to 1806 and early 1807 , for at least part of which period the prince was away with his regiment in Holstein. No letters from the prince to Thonning have yet been found. Prince Christian is recorded to have taken a close interest in his collections, working with his specimens personally, but now, for a time at least, he found himself dependent on written reports from his curator. These letters constitute an unusual narrative account of the prince's collecting in this period. The letters place the bold young African sojourner - learned or not - very close to the center of the Danish museum world. ${ }^{33}$

The first of Thonning's letters to Prince Christian is dated March 15, 1806, and concerns first the late Holten's own insect collection. ${ }^{34}$ Thonning, in the rather delicate position of reconciling his royal patron's interest and the wishes of the esteemed servant's widow, writes:

In accordance with your High order I have spoken with Mad. Holten regarding the insects; she prefers to part with the whole collection, but, failing that, she is willing to let as many go separately as are requested.

I therefore most humbly give myself leave to inquire: whether both of Your Highness's insect collections should be regarded as separate, and thus 
to be completed independentiy; and whether the collection at Sorgenfri should not in that case have precedence in the domestic insects.

[Sorgenfri, a little north of Copenhagen, was one of the royal family's residences. The other collection was apparently at Amalienborg, in Copenhagen. ${ }^{35}$ ]

I must next request Your Highness's decision, whether I may offer a certain common price, for example 8 to 10 [skilling] for each insect, or whether Your Highness would please to make some other decision with regard to the price.

The seller of the 7 Kongsberg fossils, which, according to the catalogue, were to cost 12 [rigsdaler] 4 sk. altogether, has lowered the price to $10 \mathrm{rdl}$.

[Kongsberg was an important silver-mining district southwest of Oslo. ${ }^{36}$ ]

Thonning went on: «From Councillor of Mines Gieseke I have in all received. . . 22 pieces for Your Highness's collection». These minerals were all from the Færoes, and the island on which each specimen had been collected is named. The list includes pure copper in zeolite, from Nolsøe; grass-green rhombic zeolite, from Østerøe; and chabazite in truncated rhombuses on amygdaloid, from Viderøe. ${ }^{37}$ Thonning inquired if the prince found Giesecke's price of 25 rigsdaler for all 22 pieces acceptable. (Giesecke, a Prussian mineralogist who in his day worked in Vienna, Denmark, Norway, Sweden, and, for seven years, in Greenland (and, along the way, wrote the libretto for «The Magic Fluten), had collected for two months in the Færoes in 1805, but his specimens, with the possible exception of these twenty-two pieces, were apparently destroyed in the bombardment of $1807 .{ }^{38}$ )

Thonning then returned to the subject of Holten's collection:

Shortly before his death the late Holten was apparently negotiating about same with Prof. Vad; he is said to have asked 300 rd., and, according to the widow, Vad offered 200 rd., but since Holten's death Vad has not appeared.

[Gregers Wad was professor of mineralogy and zoology and curator of the collections of the University of Copenhagen and the Royal Natural History Museum. ${ }^{3 \text { ] }}$ ]

Finally, Thonning suggested that if the Prince bought the entire Holten collection, pieces that were not needed in his own collection could perhaps form "the basis of a collection for Your Highness's brother» (i. e., Prince Ferdinand).

Ten days later, Thonning acknowledged receipt of the prince's letter of the 18 th [of March], ${ }^{40}$ which had contained some expression of the Prince's confidence in him: Thonning tendered his "most humble thanks for the favor Your Highness intends for me; I will always strive most sedulously to be worthy of your High Favor». He went on:

Mdm. Holten knows no knowledgeable man who can assess the value of the insects; permit Your Highness therefore that I ask Councillor of State [Tønder] Lund or Prof. Schumacher about it.

I inspected the 700 minerals advertised at auction in the Adresse Avisen [an advertising newspaper] yesterday and scarcely found an indifferent piece among them all.

Two months later, Thonning reported that Professor Wad had offered 200 rigs- 
154 daler for Holten's insects, provided the collection was sold intact. ${ }^{41}$ However, Wad was not in a position to make the widow Holten a firm offer until the matter had been resolved at higher levels,

as the collection is to be bought for the National Museum, which especially lacks domestic insects; this decision has not yet been made; in the meantime Md. Holten has decided: not to undertake anything in this regard without Your Highness's knowledge and consent. ... In comparing both collections I find that Holten's has 340 Elenteratæ and 28 Rhyngotæ that are not found in Your Highness's; the other classes are for the most part not yet classified. ${ }^{42}$

It appears that the prince had also turned to him for botanical advice, for Thonning now writes: "the pleasant duty Your Highness lays on me I shall strive as much as it is within my power to discharge; it will now undoubtedly be too late to increase the arboretum with shrub or tree species, but for a number of annual plants there is still good time». Thonning makes no further mention of an arboretum in these letters, but this was perhaps the economic botanical garden established at Sorgenfri in 1793 and 1794 by Christian's father, Prince Frederik, the heir presumptive. It was Martin Vahl who laid this garden out. ${ }^{43}$

A month later, in June, doubtless in response to a demand from Prince Christian for more detailed information, Thonning reported as follows: ${ }^{44}$

Holten's insect collection is of about the same size as your own collection in town; it is kept in two new, brown-painted pinewood cabinets, of which the one is not yet provided with glass in the draw- ers; and only the two classes, namely Eleuterata and Rhyngota have been determined and arranged; the number of species can thus not very exactly be determined.

Thonning guessed the total to be about two thousand, and said that if each species was to be bought for 6-8 skilling, "(not counting duplicates)», which would be a reasonable price, then the total for the insects would be about one hundred and fifty rigsdaler; the cases had cost over fifty rigsdaler, and the collection could thus not be sold for less than two hundred rigsdaler. Thonning allowed that such a purchase would not be without drawbacks for the prince, "for you cannot use all the insects and also do not need the cabinets, which moreover are not as elegant as you might wish in your museum».

In the collection's uncatalogued state, Thonning said, it was uncertain how many of the insects were domestic, and how many not, and it would be hard to say how the collection might contribute to the one or the other of the prince's collections; but he thought Holten's insects might represent an increase of as many as seven hundred species, which, he pointed out, would be a very large addition at one time. In all, though, he said, he dared not recommend either for or against the purchase. He clearly appears to have favored the acquisition, however, and he reminded the prince that Wad still hoped to buy the insects for "the Museum». Furthermore, a new buyer had materialized,

namely the Cetti who bought Chemnitz's shell collection and sold it with so much profit in Russia; his idea is to do the same with the Holten insects; in such a case Md. Holten has promised (if Your H. 
should decide not to purchase the whole), as far as possible to separate therefrom the insects Your Highness might want. Cetti has half offered 250 rd., but the speculation without doubt depends on the result of his enterprise in the Deer Park; the purchase is thus very uncertain.

[Antonio Cetti was a maker of meteorological instruments who settled in Denmark in the 1790 s and exhibited «optical rarities" at the old amusements park on the edge of the royal deer chase a little way up the Sound coast from Copenhagen. J. H. Chemnitz, a priest, was an important amateur conchologist, large portions of whose collections are incorporated today in the University's museums. ${ }^{45}$ ]

\section{Thonning's letter goes on:}

Councillor Blumenbach in Göttingen has in a letter to Holten sent Your Highness a handsomely bound copy of Beiträge zur Naturgeschichte, 2nd edition, first part, accompanied by the enclosed letter; with respect to the book I take the liberty of asking whether you wish it sent you in the mail or if it should for the time being be placed in the library. ${ }^{46}$

[Johann Friedrich Blumenbach was highly respected in Denmark. His Handbook of Natural History had been translated into Danish by 1793, and Prince Christian had visited him in Germany in $1803 .{ }^{47}$ ]

Thonning closed most humbly with his best wishes: the prince's wedding was "perhaps taking place at the moment I write this».

On July 22, Thonning wrote to the prince: $^{48}$

I have at this moment received word from Md.
Holten that Professor Wad has been to her and offered 250 rd. for her insect collection; she has however reserved for herself 14 days to consider, so as to obtain Your Highness's orders, which she most humbly requests.

Thonning referred the prince to his last letter and concluded his note, perhaps a trifle boldly: "The interest Your Highness takes in the completeness of your domestic museum should I think especially contribute to your decision".

A few weeks later, Thonning reported: ${ }^{49}$ "Upon your orders I have bought Holten's insect collection for the sum you yourself most graciously determined, viz., 270 rd., and have accepted Mdm. Holten's receipt therefor". On the widow Holten's behalf he offered the most humble thanks, for she was in no condition to write personally because of the very imminent birth of a child.

In order to supplement the prince's collection at Sorgenfri with the best specimens from Holten's collection, Thonning said, the collections would need to be brought together, so they could be compared. Either the Holten collection would have to be moved to Sorgenfri, or the prince's insects at Sorgenfri would have to be brought to town. The Sorgenfri insects occupied only one cabinet, and Thonning preferred to move this collection, although there would in that case arise a shortage of space in the Copenhagen premises.

Thonning then remarked:

Prof. Schumacher's excellent mineral collection, upon which he has lavished so much diligence and expense, and which, with little doubt, is the most complete and most instructive in the land, is now 
156 in danger of falling prey to a German mineral dealer or a Russian museum, for he has determined to sell it.

There is no further mention of Schumacher's collection in these letters; portions of it, at any rate, were purchased somewhat later by J. G. Moltke and donated to the University. ${ }^{50}$

Early in 1807 another interesting collection came on the market, and Thonning again acted for Prince Christian. ${ }^{51}$ He wrote:

I take the liberty of forwarding the catalogue of the Hemmert natural history collection, the auction of which will begin about the 23rd of February; in part because the catalogue was published so late, and in part because of the time it required to compare it exactly with Your Highness's collection, I hope I may be excused for not having been able to send it before.

[Joost von Hemert was a wealthy merchant, whose fortunes were tied up with those of the African, Asiatic, and West Indian and Guinean companies; his natural history collections enjoyed some reknown in Copenhagen. His son, Peter von Hemert, was not lucky, and drove the family business into receivership in 1805 . When he died in 1810, his financial affairs had not yet been finally settled; this auction of natural historical specimens in 1807 may have been one of the steps in this drawn-out proceeding. $\left.{ }^{52}\right]$

Thonning went on:
So that Your Highness can as quickly as possible survey the whole, I have marked in the catalogue those things which best suit Your H.'s collection; I have arranged it thus, that I have simply designated with an $\mathrm{x}$ - those minerals which it would be agreeable to own to complete the suite; - with $\mathrm{xx}$ - the minerals which the collection probably should not lack; - and with $\mathrm{xxx}$ - the minerals which the collection absolutely should not be without, provided that the minerals match the catalogue, which I must presume they do, as it was prepared by Prof. Wad.

Where I have found it necessary to remark something, I have put a ? and written No. and remark on the enclosed sheet.

Neither the catalogue nor Thonning's attached notes is preserved in this archival context. He went on:

I have seen some of the shells, and judging by these the collection is extremely fine; I hope next week to be able to inspect the whole. Should Your Highness want any of either the minerals or shells, I ask your Most Gracious order regarding it with the first post, as well as how much you determine to spend for each lot.

\section{Several weeks later, Thonning reported: $:^{53}$}

With regard to the Hemmert mineral auction, I hereby most humbly take the liberty to notify Your Highness that I have got most of the pieces I marked for your collection, but some I had to forgo, as they were driven up too high. With most numbers there followed a whole series of the previous, which found no buyer until one good piece or another came up; some numbers were therefore dearer than

On the next two pages: Peter Thonning's letter to Prince Christian of Denmark, March 31, 1807, regarding the purchase, at the "hemmertske Mineralie Auction", of specimens for the prince's collection. Reproduced with the permission of the Danish Royal Court. 
(2), Binips

$2, s_{i}, 2$

0

0 . -

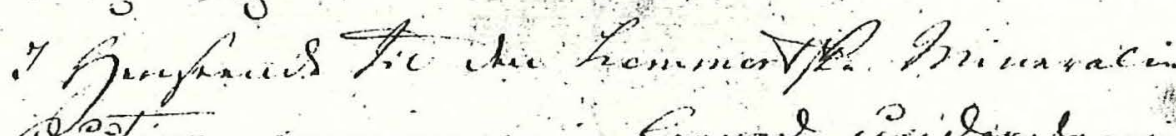

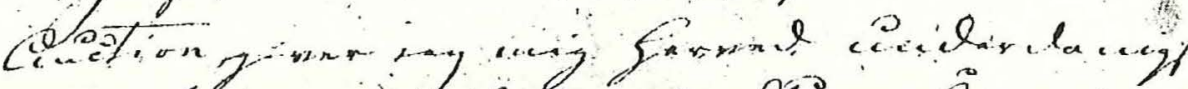

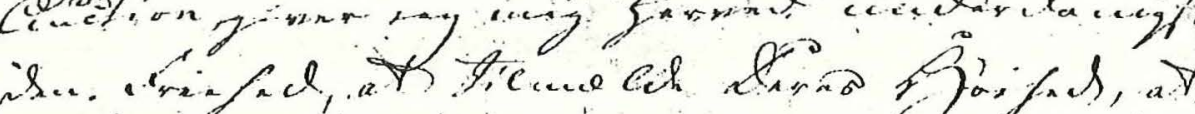

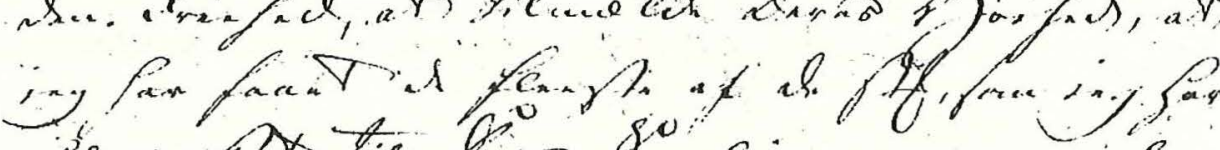

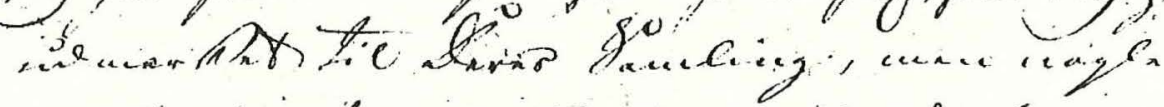

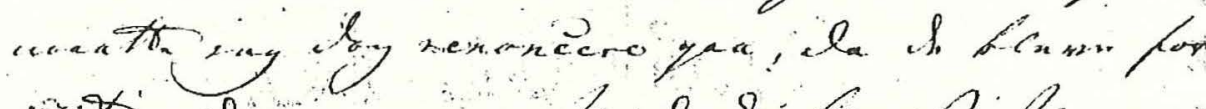

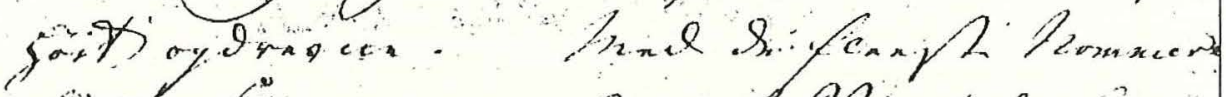

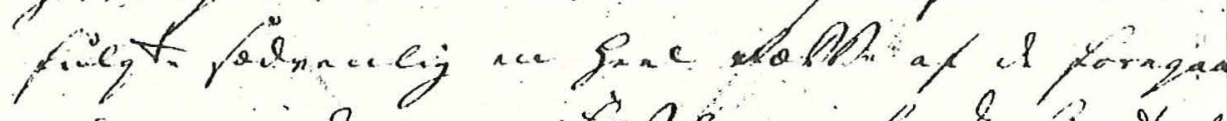

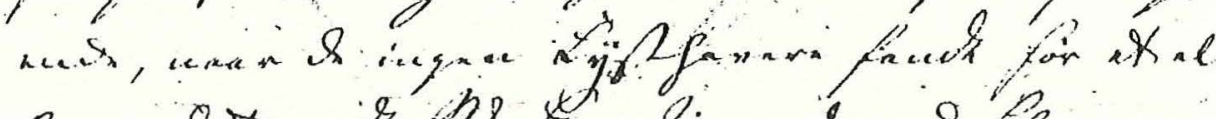

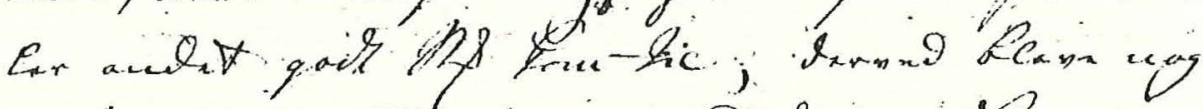

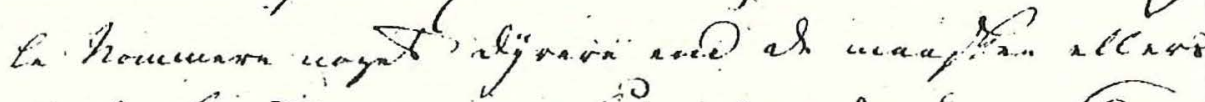

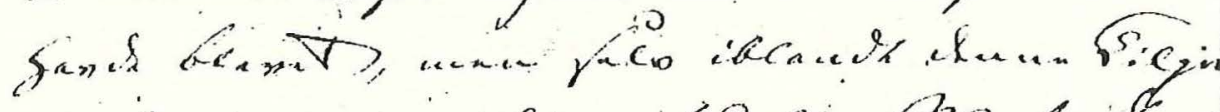

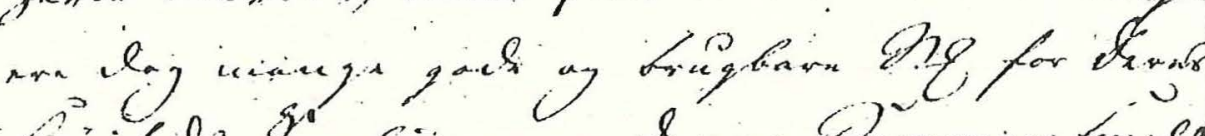

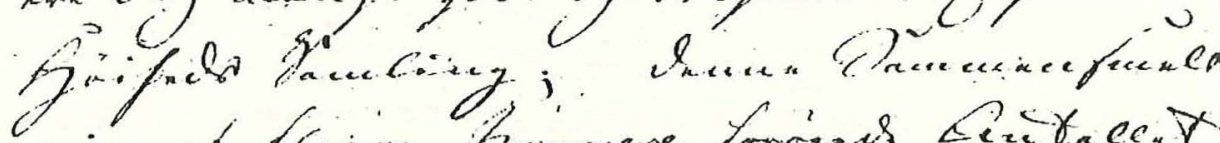

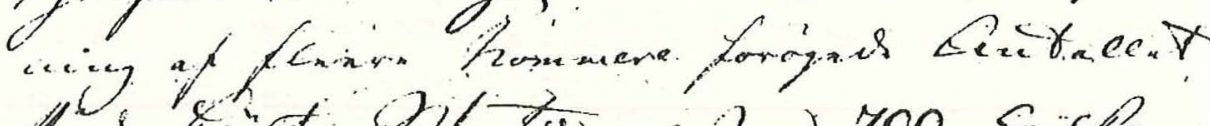

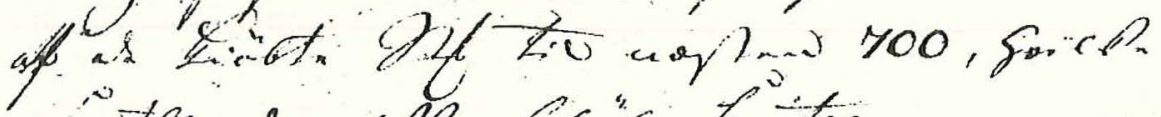

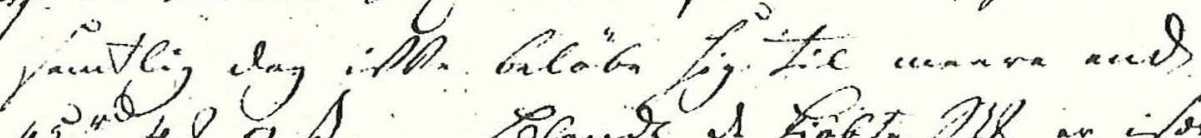

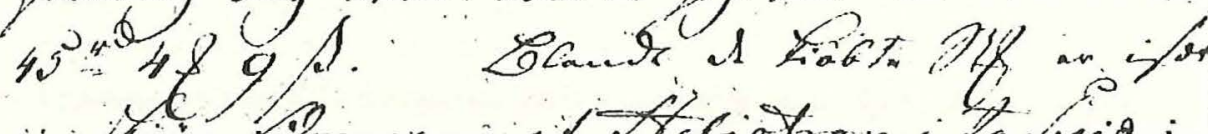

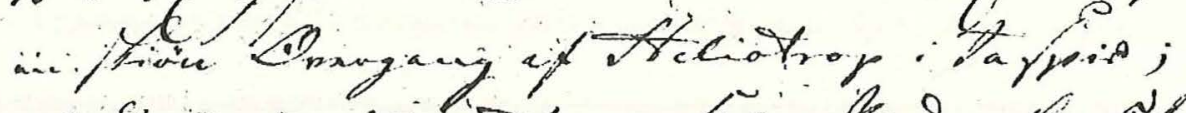

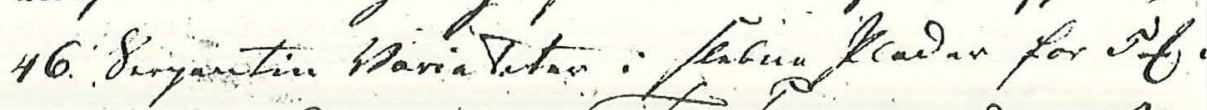

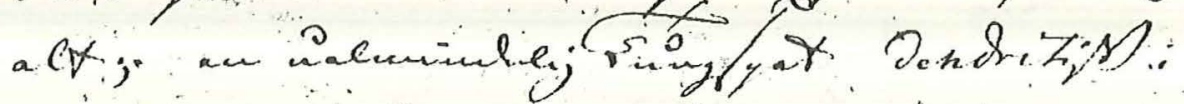




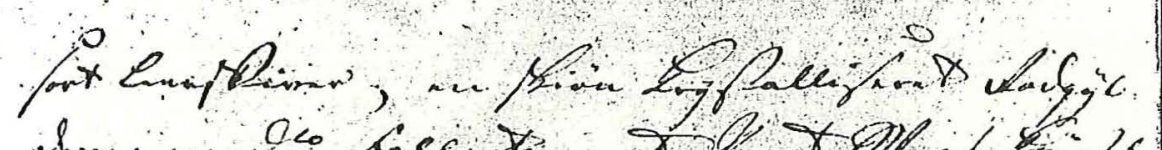

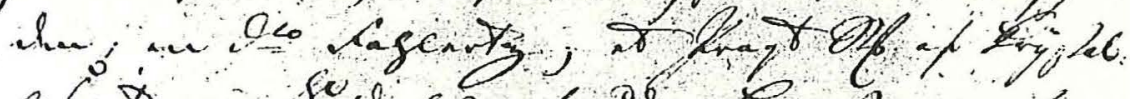

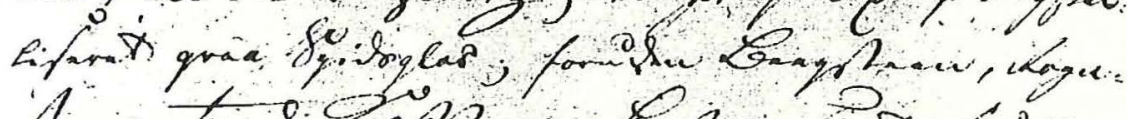

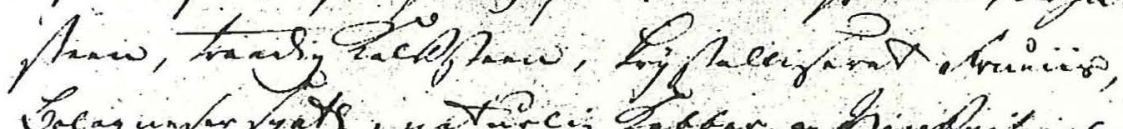

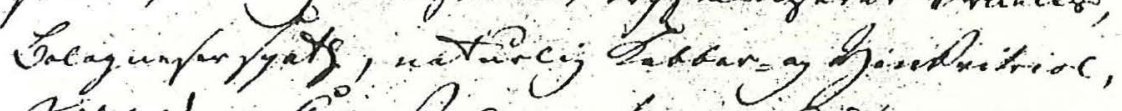

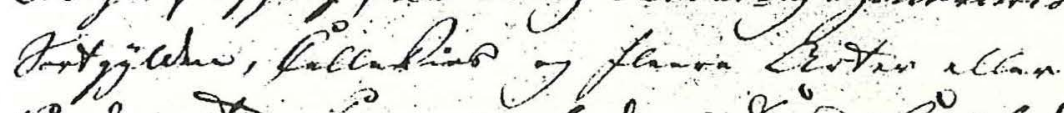

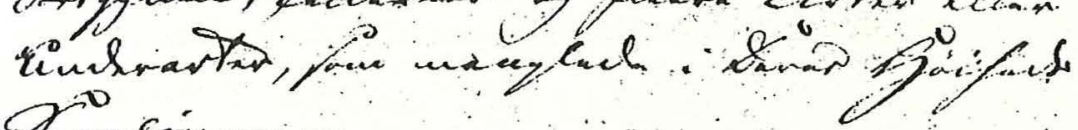
Dawering

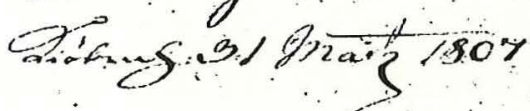

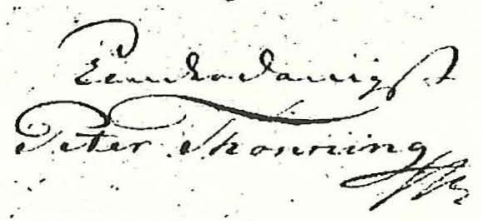


they perhaps otherwise would have been, but even among these thrown in are many good and serviceable pieces for Your Highness's collection; this combination of several numbers increased the number of the pieces purchased to almost 700 .

All this had cost a little over forty-five rigsdaler. Thonning listed a few of the most interesting pieces he had bought for the prince, including 46 serpentine varieties in polished plates, an unusual dendritic barite in black clay slate, and a lovely crystallized fahlerz.

In his résumé of December 1809, Thonning stated that he was still in charge of the prince's collections, but no further letters from Thonning to the prince regarding the collections are preserved. The bombardment of 1807 devastated Copenhagen, and Denmark's involvement in Napoleon's war with England for the next seven years may have rather stifled the market in minerals and insects. At any rate, Thonning's service to the royal family apparently gave satisfaction: when Prince Ferdinand outgrew his tutors, Thonning was placed in a choice position at the General Customs Chamber. ${ }^{54}$

Perhaps mainly as a result of his failure to publish any of his own scientific work, Thonning remains relatively obscure, but he is an important figure of early-nineteenth-century Danish science and society. The record of his curatorship, although not extensive, adds telling detail to our picture of the formation of a great natural history collection at the very top of the Danish museum world. It further reconfirms the historical connections between Christian, the scientist king, and the ideas and central personalities of the old Natural History Society, which had been formed when the prince was still a young child. ${ }^{55}$

Thonning's career was by no means typical, and it is noteworthy that a man of such an unusual background should have been placed in such intimate contact with the royal family and in charge of so promising a natural history collection. Thonning had behind him a scientific achievement of the utmost respectability, but he also had tales to tell of wildly exotic and beautiful tropical landscapes; of peoples and lives inconceivably foreign to the experience of metropolitan Danes; of deadly tropical fevers and vast floods on huge rivers the like of which do not exist in Scandinavia; of medicines prepared, in houses of sticks and mud and palm fronds, from the very plants he was gathering for the cabinets of some of the most polished gentlemen of Denmark; of dinner companions who kept chained in their compounds inventories of slaves, whose warehouses were stacked with the tusks of elephants, and who traded Danish rifles and rolls of sweet Brazilian tobacco and textiles of every stripe and from every corner of the world for gold dust panned in the streams of Akvapim and Akim. ${ }^{56}$ In the anti-scholastic rhetoric of natural history at the end of the eighteenth century, it was a commonplace that the "book of nature» itself was the natural historian's primary text; ${ }^{57}$ Peter Thonning had read more widely therein perhaps than most. This was the man the young Prince Christian relied on to act as his eyes and ears in the market for natural historical specimens, and who botanized with the lazy Prince Ferdinand in the woods and fields around Sorgenfri. ${ }^{58}$

When Thonning's career carried him into public administration, he appears to 
160 have largely abandoned the formal pursuit of science, although, to be sure, few clues to his private interests have emerged from the record. He is not known to have collaborated actively with Schumacher on the publication of his Guinea flora. According to Kai Henriksen, Thonning was recalled by a descendant to have enjoyed collecting insects in the countryside around Copenhagen. ${ }^{99} \mathrm{He}$ was among the members of the Danish Natural Historical Union established in the 1830 s by J. F. Schouw and D. F. Eschricht, ambitious representatives of a new generation of scientists. ${ }^{60}$ There is further, at the Royal Library, an undated letter from Thonning in response to an inquiry from his friend J. W. Hornemann, at the Botanical Garden, probably in connection with Hornemann's article, published in 1837, on plants named for Danish scientists. ${ }^{61}$ Most notably, Thonning was appointed, with Hauch, Wad, and Vargas Bedemar, to the Board of Directors of the Royal Museum of the Natural Sciences, which was formally put on a permanent footing by Frederik VI in 1829. Thonning served on this Board until his death, but it is likely that his rôle was more administrative and political than scientific. ${ }^{62} \mathrm{He}$ ascended to the rank of Second Deputy in the General Customs Chamber, retiring when the central administration was reorganized in 1840. ${ }^{63}$ Thonning and Christian VIII died a few weeks apart early in 1848 .

\section{NOTES}

1. Karen Callisen, «Til Mineralogisk Museums Historie. Kong Christian VIII og hans particulaire mineralogiske Cabinet", Meddelelser fra Dansk Geologisk Forening, Vol. 10, 1941, pp. 506-531; Ragnar Spärck, Zoologisk Museum i Kobenhavn gennem tre aarhundreder (Copenhagen: Ejnar Munksgaard, 1945), p. 37.

2. Axel Garboe, Geologiens historie i Danmark (Copenhagen: C. A. Reitzels Forlag, 1959-61), Vol. I, pp. 188, 190.

3. Callisen, p. 509; Garboe, II, pp. 238-240; Spärck, Zoologisk Museum, p. 42; Kai L. Henriksen, "Oversigt over dansk entomologis historie», Entomologiske Meddelelser, Vol. XV, 1921-37, p. 169.

4. Callisen, pp. 510 ff.; Henriksen, p. 112; Garboe, I, p. 189-90; see also Axel Linvald, ed., Kong Christian VIII.s breve 1796-1813 (Copenhagen: Det Kongelige Danske Selskab for Fædrelandets Historie, G. E. C. Gads Forlag, 1965), Vol. II, p. 232. An undated inventory prepared by Holten is the most important source for the nature and extent of Christian's collection around the turn of the century; it is preserved in the archives of the University of Copenhagen's Geological Museum.

5. Garboe, I, pp. 216-20; Callisen, pp. 520-29.

6. Rigsarkivet, Rentekammeret, 2214.86, Breve, Dokumenter og Akter vedk. partikulære Personer, T. [1679-1848], Box 31, P. Thonning's curriculum vitæ, Copenhagen, December 20, 1809; «Thonning, Peter», Dansk biografisk leksikon, 3rd ed., Sv. Cedergreen Bech, ed. (Copenhagen: Gyldendal, 1979-84); Georg Nørregård, Guldkysten, Vol. 8 of Vore gamle tropekolonier, Johannes Brøndsted, ed., 2nd ed. (Copenhagen: Fremad, 1966), pp. 282-83.

Unless otherwise stated, all archival material cited here is to be found at the Rigsarkiv.

7. Kongehusets Arkiv, Christian VIII, Breve fra for- 
skellige, Number 159, Tetens-Trepka:

Thonning, Peter, 1806 (6), 1807 (2); two letters dating to 1815 and 1816 have nothing to do with natural history; Callisen, p. 520, says only that «it is known» that Thonning had supervision of the collections for several years and passes quickly on to Vargas Bedemar; Axel Linvald refers to these letters in Kong Christian VIII. Den Unge Prins 1786-1813 (Copenhagen: Gyldendalske Boghandel, 1943), p. 146; Henriksen, p. 169, knew that Thonning represented the prince at auctions, but he seems to cite as his source a personal communication from one of Thonning's descendants. Garboe apparently does not discuss Thonning's work for the prince.

8. Henriksen, pp. 112, 167.

9. Kongehusets arkiv, Frederik VI, Box 27, Rapporter om prins Frederik Ferdinands opdragelse, 1805-06, Blücher's Rapporter, 1805-06, Holten, Copenhagen, December 21, 1805, to Crown Prince Frederik. Holten affected a beautiful italic script instead of the Gothic typical of the period. All translations from Danish sources are by the author of this article; punctuation has been modernized in places.

10. Garboe, I, p. 189; Linvald, Kong Christian VIII.s breve, I, pp. 27-28.

11. Dansk hof-og statskalender, 1806, column 52; Blücher's Rapporter, 1805-6, Sommer, Copenhagen, January 4, 1806; Garboe, I, pp. 188, 163-64; Henriksen, pp. 110-11; Schumacher's obituary in Dansk LitteraturTidende, 1831, pp. 52-63.

12. Blücher's Rapporter, 1805-6, Sommer, January 31,1806 , to Blücher.

13. Generaltoldkammer (General Customs Chamber), Guineisk Kopibog, July 2, 1799, to Tonning [sic].

14. Thonning's report is to be found in Departementet for udenlandske Anliggender, Gruppeordnede sager, Guinea, 1775-1847, Box 872, Thonning, [Copenhagen], December,
1803,»Indberetning om det danske Territorium i

Guinea fornemmelig med hensyn til nærværende Kultur af indiske Kolonial Produkter eller Beqvemhed for samme», originally submitted to the Generaltoldkammer, Guineisk Journal 434/1803; see Ludv. J. F. Moltke, «Bidrag til Geheimraad Frederik Moltkes Levnetsbeskrivelse", Historisk Tidsskrift, 4th Series, Vol. 2, 1870-72, pp. 1-128, on pp. 45-48, and Letters on West Africa and the slave trade. Paul Erdmann Isert's journey to Guinea and the Caribbean Islands in Columbia (1788), Fontes Historiae Africanae Series Varia VII, Selena Axelrod Winsnes, transl. (Oxford: British Academy, Oxford University Press, 1992), pp. 227-47.

15. Generaltoldkammer, Vestindiske Forestillinger og Resolutioner, resolution of October 2, 1799 (No. 34 a. and b.), and Guineisk Kopibog, July 16, 1799, to Thonning.

16. Tønder Lund's and Ove Sehested's jointly owned collection was fundamental to the systematic work of J. C. Fabricius. Ella Zimsen, The type material of I. C. Fabricius (Copenhagen: Munksgaard, 1964), pp. 9-12. I am grateful to Børge Petersen, of the Zoological Museum, Copenhagen, for drawing my attention to this work.

17. Indbydelse til et Selskabs og en National Stiftelses Oprettelse for Naturbistorien, isar Fadrenelandets (Copenhagen: Tryk hos Johan Frederik Schultz, 1789); Henriksen, pp. 98-119; Garboe, I, pp. 162-172; Carl Christensen, Den danske Botaniks Historie (Copenhagen: H. Hagerups Forlag, 1924-26), Vol. I, pp. 90-92.

18. Kommissionen for Museet for Naturvidenskaberne (1796-1829), Journalsager, Box I, 1796-1811, No. 6, Pro Memoria, June 26, 1804 , signed by the directorate of the Natural History Society.

19. Christensen, I, pp. 91-92; Henriksen, p. 102, 112; Garboe, I, pp. 163, 189. 
162 20. Thonning's curriculum vitæ, December 20, 1809; Henriksen, p. 105; Botanisk Centralbibliotek, Copenhagen, J. W. Hornemann to N. Hofman (Bang), No. 2, Nov. 22, 1803; Niels Hofman (Bang) to Martin Vahl, No. 9, [January 29,] 1804.

21. M. Vahl, «Beskrivelse over nye Planteslægter», Skrifter af Naturhistorie-Selskabet, Vol. VI, 1810, pp. 84-128, on pp. 124-25; J. W. Hornemann, "Om de danske, norske og holstenske Botanikere og Botanikens Yndere, som have nydt den Ære, at deres Navne ere blevne tillagte Planteslægter til Erindring om dem," Naturhistoriske Tidskrift, Series 1, Vol. I, 1837, pp. 550-597, on p. 585; C. D. Adams, "Activities of Danish botanists in Guinea 1783-1850», Transactions of the Historical Society of Ghana, Vol. III, Pt. I, 1957, pp. 30-46, especially p. 42; F. N. Hepper, The West African herbaria of Isert and Thonning (Kew: BenthamMoxon Trust, Royal Botanical Gardens, 1976).

22. Generaltoldkammer, Guineisk Journal 270/1802, Thonning, Christiansborg Fort on the Coast of Guinea, April 24, 1801, one of two letters of this date; Henriksen, p. 152; Spärck, Zoologisk Museum, p. 37.

23. Thonning's «Indberetning om det danske Territorium i Guinea», $\$ \$ 16,17,19$.

24. Botanisk Centralbibliotek, Niels Hofman (Bang) to Martin Vahl, No. 9, [January 29,] 1804, and No. 10, June 2, 1804.

25. Christensen, I, p. 171, and II, pp. 87-88.

26. Thonning's curriculum vitæ, December 20 , 1809.

27. Blücher's Rapporter 1805-6, Sommer, February 18,1806 , and Thonning, Copenhagen, February 17,1806 , both to Blücher.

28. Kongehusets arkiv, Frederik VI, Boxes 27-29, Rapporter om prins Frederik Ferdinands opdragelse, 1805-1810.

29. Kongehusetsarkiv, Frederik VI, Box 27, Rapporter om prins Frederik Ferdinands opdragelse, 1805-1806, Bardenfleth's Rapporter, 1806,
Bardenfleth, Sorgenfri, October 13, 1806, to the Crown Prince (Frederik VI), «Kort Udsigt over enhver af Hans Høihed Prinds Ferdinands Lærers Methode".

30. Bardenfleth's Rapporter, Bardenfleth, August 23, 1807.

31. Thonning's curriculum vitæ, December 20, 1809.

32. F. C. Schumacher, Beskrivelse af Guineiske Planter som er fundne af danske botanikere, isar af Etatsraad Thonning (Copenhagen, trykt i Hartv. Frid. Popps Bogtrykkerie, 1827); according to Christensen, II, p. 117, the study was presented to the Royal Danish Academy of Sciences and Letters in 1826 and published in the Academy's Skrifter in 1828 and 1829.

33. "Christian VIII", Dansk biografisk leksikon, 2nd ed., Povl Engelstoft, ed. (Copenhagen: J. H. Schultz Forlag, 1933-44); Axel Linvald's selective collection of Christian's correspondence, Kong Christian VIII.s breve, casts some light on the prince's scientific interests but makes no mention of Thonning; Callisen, p. 528; letters to Christian VIII, from Peter Thonning, 1806-1807 (see note 7 above).

34. Letters to Christian VIII, Thonning, Copenhagen, March 15, 1806.

35. Henriksen, p. 168; Callisen, p. 529.

36. Garboe, I, pp. 45, 48.

37. James Murowchick kindly advised me on the translation of the descriptions of minerals herein.

38. Garboe, I, p. 198; "Giesecke, Karl Ludvig”, Dansk biografisk lexikon, C. F. Bricka, ed. (Copenhagen: Gyldendalske Boghandels Forlag, 1887-1905).

39. Henriksen, pp. 148-50; Garboe, I, pp. 172-77, 183-84.

40. Letters to Christian VIII, Thonning, Copenhagen, March 25, 1806.

41. Letters to Christian VIII, Thonning,

Copenhagen, May 20, 1806.

42. These appellations are presumably Holten's; 
note also that Thonning's spellings are not consistent within this series of letters.

43. Christensen, I, p. 163, footnote 1. It may be that this is the garden referred to in Christian's letter to N. I. Schow, September 10, 1803, in Linvald, Kong Christian VIII.s breve, p. 232.

44. Letters to Christian VIII, Thonning, Sorgenfri, June 21, 1806.

45. "Cetti, Giovanni» (Antonio Cetti's son), Dansk biografisk leksikon, 3rd ed., Sv. Cedergreen Bech, ed. (Copenhagen: Gyldendal, 1979-84); Garboe, I, p. 96; «Chemnitz, J. H.», Dansk biografisk leksikon, 2nd ed.

46. See Linvald, Kong Christian VIII.s breve, Vol. 2, pp. 173 ff.; Callisen, p. 516.

47. Garbo, I, pp. 175, 271 (note 282).

48. Letters to Christian VIII, Thonning, Sorgenfri, July 22, 1806.

49. Letters to Christian VIII, Thonning, Sorgenfri, August 16, 1806.

50. Henriksen, p. 111; Garboe, I, p. 196.

51. Letters to Christian VIII, Thonning,

Copenhagen, February 14, 1807.

52. "von Hemert, Joost», Dansk biografisk leksikon,

2nd ed.; Breve fra og til Gregers Wad 1790-1812,

Ad. Clément, ed. (Copenhagen: [Clement,] H.

H. Thieles Bogtrykkeri, 1928), pp. 90, 115.

53. Letters to Christian VIII, Thonning,

Copenhagen, March 31, 1807.

54. Thonning's curriculum vitæ, December 20, 1809; «Thonning, Peter», Dansk biografisk leksikon, 3rd ed.; Henriksen, pp. 114-15.

55. Callisen, pp. 510-11.

56. Thonning's «Indberetning om det danske

Territorium i Guinea; Nørregård, Guldkysten;

Kay Larsen, De Danske i Guinea (Copenhagen:

Nordiske Forfatteres Forlag, 1918); Thonning's notes on the Africans' uses of plants are reproduced in Schumacher, Beskrivelse af Guineiske Planter and translated in Hepper, West African herbaria of Isert and Thonning.

57. For example, Henrik Steffens, «Botanikens
Skæbne i Danmark», in Carl Ludwig Wildenow,

Udkast til en Larebog i botaniken, Henrik

Steffens, trans. (Copenhagen: C. L. Buch's

Forlag, 1794), p. 349.

58. Rapporter om prins Frederik Ferdinands opdragelse, 1805-1810.

59. Henriksen, p. 114.

60. Spärck, R. «Dansk naturhistorisk Forening i

København 1833-1933", Videnskabelige

Meddelelser fia Dansk naturhistorisk Forening $i$

Kobenhavn, Vol. VC, 1933, pp. 1-148, on pp. 2, 6, 17.

61. Royal Library, Copenhagen, Haandskrift Afd., Abr. Autogr. $4^{\circ}$ H. 124, Nrs. 2143-2160,

Thonning, undated, to Etatsraad Professor Hornemann, Ridder and Dannebrogsmand, which latter honorific dates the letter to 1836 or thereafter; "Hornemann, Jens Wilken", Dansk biografisk leksikon, 3rd ed.; Hornemann, «Om de danske, norske og holstenske Botanikere og Botanikens Yndere", pp. 550-597.

62. C. C. A. Gosch, Jorgen Christian Schiodte (Copenhagen: Gyldendalske Boghandels Forlag, F. Hegel \& Søn, 1898-1905), Part I, pp. 77-79, 320.

63. Generaltoldkammer, Sekretariatet, Christian VIII's resolutioner og rescripter vedkommende Generaltoldkammerets sager 1840-1847, No. 10, Allerunderdanigst Forestilling, Lowzow, Dec. 14, 1840, Resolution of Dec. 19, 1840.

\section{ABSTRACT}

A series of letters regarding the natural historical collections of Prince Christian (VIII) of Denmark is here placed in historical context. These eight letters, dating to 1806 and 1807 , were written by Peter Thonning, the curator of the collection from 1806 to 1809 . The letters and associated materials cast light on the recruitment of this interesting 
DANIEL HOPKINS

164 figure of Danish science, who is best known for his West African botanical expedition; on the nature and workings of the Copenhagen market in natural historical specimens; and on some of the connections among natural history, national policy, and colonialism.

\section{ACKNOWLEDGEMENTS}

I am very grateful for the assistance and advice of Ella Hoch, of the Geological Museum, Erik Gøbel, of the Rigsarkiv (both in Copenhagen), James Murowchick, of the University of Missouri Kansas City, and Marty Ross. My research on Peter Thonning has been supported by the Carlsberg Foundation, the U. S. National Endowment for the Humanities, and the University of Missouri Research Board.

Daniel Hopkins is Associate Professor of geography in the Department of Geosciences at the University of Missouri - Kansas City. He specializes in the historical geography and cartography of the Danish tropical colonies.

Adr: Department of Geosciences,

University of Missouri - Kansas City,

Kansas City, Missouri, 64110, U. S. A.

Fax: +1-816-235-5535

e-mail:dhopkins@cctr.umkc.edu 